tionship with associates in Japan. A statement in a letter from his close friend and admirer Professor Fumio Yamashita is "I would say that you are like Admiral Perry who visited Japan on a black ship in 1853 and opened our country to the international community." In addition, he has applied his acumen in epidemiologic investigation to the complex entity known as sudden infant death syndrome. As a result of this new dedication, the language of our awardee was renovated, and words like stratification, randomization, significance, and cohort have now become prominent in his speech replacing GFR, electrolytes, sodium-space, and solute-load.

In 1981 he became Emeritus Professor, and retired from the world of kudos, "approved but not funded," and "how many papers do you have" to his new career in child health and welfare as Medical Director of the Children's Aid Society, New York. In a sense, this is a culmination of all that has gone before. It is an opportunity to apply the various stimuli received from his mother, the exposure to tragedy as epitomized in Nagasaki, the critical eye of the scientist, the background of the clinician, and the analytic approach of public health and epidemiology.

What have we, then (Fig. 2): Henry the athlete, the psychologist, the renal physiologist, the department chairman, the clinician, the administrator, the writer, the epidemiologist, the husband and father, and now the violinist? My answer is no. None of those singly, but all together make Henry L. Barnett, the scientist-philosopher pediatrician an heir of Howland, Marriott, Hartmann, and Levine, prepared to take his place with his illustrious predecessors, the previous Howland awardees.

Colleagues, I give you Henry L. Barnett, the compleat pediatrician.

All the world's a stage,

And all the men and women merely players.

They have their exits and their entrances,
And one man in his time plays many parts,

His acts being seven ages.

William Shakespeare As You Like It Act JI, Scene 7

\section{REFERENCES}

1. Saxe G 1948 The blind men and the elephant. In: Adshead GI, Duff A (eds) Inheritance of Poetry. Cambridge, MA, Houghton Mifflin Co, pp 97-98

2. Sherman DH (Chairman). Semi-Centennial Volume of the American Pediatric Society, 1888-1938. Privately printed, pp vii-534

3. Faber HK. McIntosh R 1966 History of American Pediatric Society $1887-$ 1965. Blakiston Division, McGraw-Hill Book Co, New York, pp v-375

4. Barnett HL 1960 Attitudes in pediatric research. Am J Dis Child 100:459

5. Barnett HL 1940 Renal physiology in infants and children. I. Method of estimation of glomerular filtration rate. Proc Soc Exp Biol Med 44:654

6. Barnett HL 1966 Paediatric nephrology: the scientific study of the kidneys and their diseases in infants and children. Arch Dis Child 41:229 (The George Fredrich Still Memorial Lectures. Delivered at the Annual Meeting of the British Paediatric Assn. in Scarborough, April 22, 1965)

7. Spitzer A (ed) 1982 The Kidney during Development, Morphology and Function. Masson Publishing Co, New York, pp 1-387

8. Barnett HL. Hare K. McNamara H, Hare R 1948 Influence of postnatal age on kidney function of premature infants. Proc Soc Ep Biol Med 69:55

9. Barnett $\mathrm{HL}, \mathrm{McNamara} \mathrm{H} 1951$ Electrolyte balances in a male infant with adrenocortical insufficiency and virilism. The effect of desoxycorticosterone acetate and salt therapy with special reference to potassium. J Clin Invest 30:227

10. Levine SZ, Barnett HL, Bierman CW, McNamara H 1951 Effect of ACTH and some adrenocortical steroids on the metabolism of tyrosine and phenylalanine in premature infants. Science 113:311

11. Kretchmer N. Levine SZ. McNamara H, Barnett HL 1956 Certain aspects of tyrosine metabolism in the young. I. The development of the tyrosine oxidizing system in human liver. J Clin Invest 35:256

12. Report of the International Study of Kidney Disease in Children (HL Barnett, Director) 1978 Nephrotic syndrome in children: prediction of histopathology from clinical and laboratory characteristics at time of diagnosis. Kidney Int 13:159

\title{
Acceptance of the John Howland Medal and Award of the American Pediatric Society for 1984
}

\author{
HENRY L. BARNETT \\ The Children's Aid Society New York, New York 10017 and Albert Einstein College of Medicine, Bronx, New \\ York 10461
}

I am very grateful to the members of the American Pediatric Society for selecting me for the John Howland Medal and Award for 1984. My pride and pleasure in receiving it are heightened by the fact that just 20 years ago I had the honor to introduce my teacher and cherished friend, the late Samuel Zachary Levine, to receive the Award. It is enhanced further by my being introduced today by my dear friend, former student, and also my teacher, Norman Kretchmer. I'm very pleased, too, that the Award was presented to me today by Joseph Dancis, who knew my wife Shirley, though not in the biblical sense, before I met her 45 years ago.

Dr. Kretchmer has alluded to Shakespeare's description of the seven ages of man. In a remarkable address to students entering Cornell University Medical College in 1958, Dr. Levine used this concept to describe the seven ages of medical man that he believed traced the evolution of a physician. Today, I have tried to recall the stages involved in my own evolution as a physician. Norman has presented his very generous assessment of my professional career. In response, I would like to reveal my own recollections of the personal motivations and satisfactions that determined it. Working now in a child welfare agency, I have wondered especially how much the social value of my work influenced my career choices.

All of us in medicine, and especially in pediatrics, have the satisfaction that we are contributing to the health and well being of others and this assures us, in a sense, that our work is socially useful. However, I suspect that the choices determining the course of our careers are probably motivated less by this general belief in our social usefulness than by the immediate gratifications we get from what we do.

I cannot recall when, or even why, I became certain that I wanted to be a physician. I assume that, among other reasons, I 
had the general motivation, described by my friend, Joseph Cramer, of wanting to be on the right side of the desk. Having not been psychoanalyzed, I shall not explore this career choice further. However, I can recall several reasons why I was attracted to pediatrics. As a summer camper and later a counselor, I had enjoyed teaching and being with children. I also had had close and very rewarding contact with children in the preschool my mother ran in St. Louis and I was very proud of her when, after the age of 50 , she received her masters degree in child development and preschool education from Columbia University. Finally, as a medical student, I had a professor of physiology, Dr. Harvey Lester White, who, starting as a pediatrician, had a major interest in developmental renal physiology and steered me to Doctors William McKim Marriott and Alexis F. Hartmann and to pediatrics.

My first major decision was to enter academic pediatrics rather than practice. This choice, I believe, was motivated almost entirely by my scientific interest and the excitement of obtaining new knowledge, a thrill I had during my pediatric residency and which I still recall vividly. I also derived deep gratification from teaching and from practice of a pediatric specialty but during this period these were secondary to the actual enjoyment of doing research.

My next major career choice was made about 10 years later when I decided to give up devoting most of my time to research in developmental renal physiology and clinical nephrology to develop and administer a new Department of Pediatrics. There were many motivating factors for this decision, including prestige, salary, and a not uncommon urge at age 40 for a career change. However, I think there was also a belief that establishing and being Chairman of a new Department of Pediatrics was more socially useful than what I had been doing. It was an opportunity to support not only the scientific but also the psychosocial aspects of pediatrics that Dr. Milton Senn had pioneered in Dr. Levine's department. This belief increased steadily during the next 25 years during which I had the privilege of teaching a large number of medical students, pediatric house officers, and research fellows, and of guiding and working with many very talented and productive pediatric teachers, investigators, and clinicians, many of whom are prominent members of this Society. I also had the satisfaction of editing a textbook, Pediatrics, and participating in international pediatric education and research, defined by Dr. Levine as the seventh and last age of medical man.

At that time in my career, 45 years after entering academic pediatrics, I had the opportunity of becoming Medical Director of The Children's Aid Society of New York City, founded in 1853 and now one of the largest and finest child welfare agencies in the country. As a Trustee of The Society over a period of years, I had a keen appreciation of the importance and effectiveness of its wide range of services for poor and troubled children and their families. Accepting this position represented a drastic change in my career, but one in which I could use my earlier training and skills as I learned how to deal with the special medical problems of children requiring foster care, many of whom were abused and neglected. Again, the decision was motivated by many factors. My 26 years at Albert Einstein College of Medicine had provided the greatest satisfaction of my academic career and I was and am proud to have been a part of it. However, I was feeling what is described in social work as "burnout" from the problems of competitive recruiting of faculty, obtaining research and training grants, and the inevitable departmental and interdepartmental administrative squabbles, a few of which Shirley characterized as massacres. Also, my motivations were becoming increasingly determined by the social value of my professional activities, and work in an outstanding and innovative child welfare agency portended great gratifications. These expectations have been fully realized during the last $2 \frac{1}{2}$ years at The Children's Aid Society.

Finally, during the past year, I have become active in the Physicians for Social Responsibility, motivated almost wholly by my appreciation of its social usefulness. This organization is making an appropriate and effective contribution to the most crucial of all present social issues, the prevention of nuclear war, and participating in it gives me a very deep sense of fulfillment.

Throughout these remarks I should have described these professional motivations and satisfactions during various stages of my evolution as a physician as "ours" rather than "mine," since they could not have existed if they had not been shared fully and throughout by Shirley and for many years by our children, Judith and Martin. Together we are very proud and pleased that I am receiving the Howland Award and Medal for 1984 and, again, I am grateful to the American Pediatric Society for this high honor. 